Piotr SZCZYGIEŁ ${ }^{1}$, Anna KUROWSKA ${ }^{2}$, Anna NIKODEM ${ }^{3}$, Izabella RAJZER ${ }^{4}$

Opiekun naukowy: Izabella RAJZER ${ }^{4}$

DOI: https://doi.org/10.53052/9788366249837.23

\title{
GRADIENTOWE RUSZTOWANIA BIOLOGICZNE O ZMIENNEJ POROWATOŚCI
}

Streszczenie: W artykule przedstawiono informacje na temat dotychczasowych autorskich prób wykonania gradientowych rusztowań biologicznych, których struktura w zależności od fragmentu sprzyjałaby narastaniu komórek kostnych lub chrzęstnych. Zaprojektowano rusztowania o różnej porowatości, a następnie wykonano je w sposób przyrostowy, techniką FDM. Struktura oraz poprawność wykonania próbek zostały zweryfikowane za pomocą techniki mikrotomografii komputerowej $(\mu \mathrm{CT})$.

Słowa kluczowe: druk 3D, biopolimery, gradient porowatości

\section{GRADIENT BIOLOGIC SCAFFOLDS WITH VARYING POROSITY}

Summary: This article contains information about recent author's attempts of producing gradient biological scaffolds with varying structure, that depending on the area, would be suitable for osteoblasts or chondroblasts proliferation. Scaffolds with varying porosity were designed and produced using FDM additive manufacturing technique. Structure and correctness of the samples were verified using micro-computed tomography $(\mu \mathrm{CT})$ technique.

Keywords: 3D printing, biopolymers, porosity gradient

\section{Wprowadzenie}

Wielkość komórek wewnątrz ludzkiego ciała różni się [1]. Projektując rusztowania biologiczne do regeneracji ubytków należy wziąć pod uwagę m.in. porowatość, która

\footnotetext{
${ }^{1}$ mgr inż., Akademia Techniczno-Humanistyczna w Bielsku-Białej, Wydział Budowy Maszyn i Informatyki, Katedra Podstaw Budowy Maszyn, ps000011@student.ath.edu.pl

2 dr inż., Akademia Techniczno-Humanistyczna w Bielsku-Białej, Wydział Budowy Maszyn i Informatyki, Katedra Podstaw Budowy Maszyn, akurowska@ath.bielsko.pl

${ }^{3} \mathrm{dr}$ inż., Politechnika Wrocławska, Wydział Mechaniczny, Katedra Mechaniki, Inżynierii Materiałowej i Biomedycznej, anna.nikodem@pwr.edu.pl

${ }^{4} \mathrm{dr}$ hab. inż., prof. ATH, Akademia Techniczno-Humanistyczna w Bielsku-Białej, Wydział Budowy Maszyn i Informatyki, Katedra Podstaw Budowy Maszyn, irajzer@ath.bielsko.pl
} 
powinna sprzyjać narastaniu komórek odpowiedniego rodzaju [2, 3]. W przypadku defektów kostno-chrzęstnych, strukturę implantu należy dostosować w taki sposób, aby ułatwić namnażanie się komórek kostnych oraz chrzęstnych [4, 5]. Komórki te charakteryzują się różną wielkością, dlatego porowatość biologicznego rusztowania również powinna być zmienna [6]. Porowatość można kontrolować za pomocą pustych przestrzeni pomiędzy poszczególnymi fragmentami i warstwami rusztowania $[7,8]$.

\section{Materiały i techniki wytwarzania}

Rusztowania wytworzono z polikaprolaktonu (PCL, Sigma-Aldrich, Mw 80 kDa), z wykorzystaniem druku 3D, techniką FDM (ang. Fused Deposition Modelling osadzania topionego materiału). Próbki zostały zaprojektowane w oprogramowaniu Autodesk Inventor a następnie przekształcone za pomocą narzędzia Prusa Slicer do postaci G-kodu, na podstawie którego drukarka może wykonać obiekt. Urządzenie, które posłużyło do wytworzenia próbek to Prusa i3 MK3. Gotowe rusztowania zostały przebadane za pomocą mikrotomografu komputerowego SkyScan 1172 Bruker®. Próbka nr 1 została wykonana przy użyciu dyszy o średnicy 0,40 mm, a próbki nr 2 i 3 przy użyciu dyszy o średnicy $0,25 \mathrm{~mm}$.

\section{Biologiczne rusztowania}

Spośród zaprojektowanych rusztowań, bliżej przyjrzano się trzem wybranym modelom, stanowiącym próbki nr 1, 2 oraz 3. Parametry zdjęć wykonanych za pomocą mikrotomografu komputerowego zestawiono w tabeli 1. Porowatość rozumianą jako udział procentowy pustych przestrzeni obiektu do objętości jego bryły, zestawiono w tabeli 2 .

Tabela 1. Parametry rejestracji za pomoca mikrotomografu 1172 SkyScan Brucker®

\begin{tabular}{|c|c|c|}
\hline & Próbka nr 1 & Próbka nr 2 i 3 \\
\hline Rozdzielczość obrazu & $12 \mu \mathrm{m}$ & $10 \mu \mathrm{m}$ \\
\hline Napięcie i natężenie lampy & $60 \mathrm{kV} / 167 \mathrm{~mA}$ & $40 \mathrm{kV} / 250 \mathrm{~mA}$ \\
\hline Czas ekspozycji & $875 \mathrm{~ms}$ & $315 \mathrm{~ms}$ \\
\hline Filtry & \multicolumn{2}{|c|}{ brak dodatkowego filtru } \\
\hline Jednostkowy kąt obrotu & \multicolumn{2}{|c|}{$0,4^{\circ}$} \\
\hline
\end{tabular}

Tabela 2. Porównanie wartości objętości próbek oraz ich porowatości, na podstawie danych uzyskanych z oprogramowania mikrotomografu komputerowego

\begin{tabular}{|c|c|c|}
\hline & Objętość $\left[\mathbf{m m}^{\mathbf{3}}\right.$ ] & Porowatość [\%] \\
\hline Próbka nr 1 & 866,785 & 23,505 \\
\hline Próbka nr 2 & 152,392 & 40,745 \\
\hline Próbka nr 3 & 177,872 & 30,862 \\
\hline
\end{tabular}




\subsection{Inspekcja próbki nr 1}

Po wykonaniu próbek, zostały one poddane inspekcji za pomocą mikrotomografu komputerowego. Projekt rusztowania oraz zdjęcia otrzymane podczas inspekcji przedstawiono na rysunku 1.
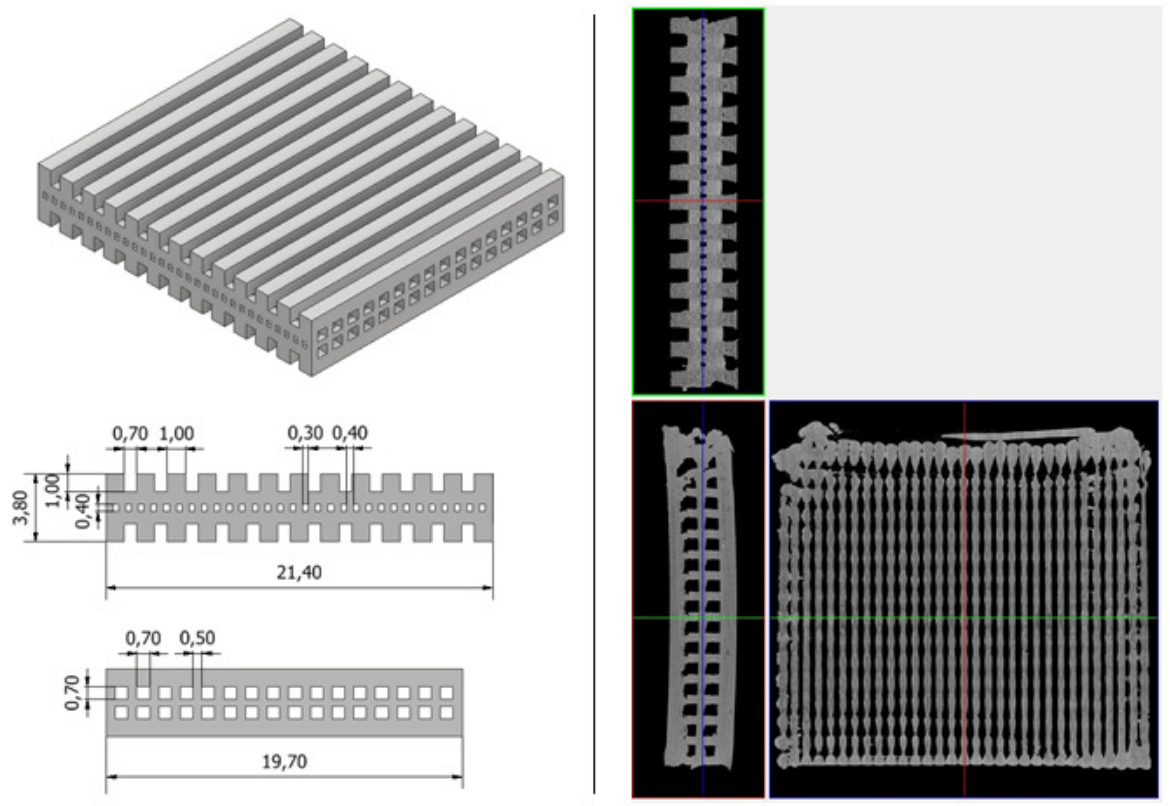

Rysunek 1. Model próbki nr 1 wraz z wymiarami (po lewej stronie) oraz fotografia $\mu C T$ środkowej warstwy rusztowania (po prawej stronie)

Rusztowanie zostało wykonane z pięciu różnych warstw, a jego całkowite wymiary wynosiły 21,40 x 19,70 x 3,80 mm. Najmniejsza zaprojektowana szerokość ścianki wynosiła 0,40 $\mathrm{mm}$, dlatego możliwe było wykonanie wydruku za pomocą standardowej dyszy o średnicy $0,40 \mathrm{~mm}$. Najmniejsze puste przestrzenie znajdowały się na środkowej warstwie i wynosiły $0,30 \mathrm{~mm}$. Takie szczeliny są możliwe do uzyskania przy użyciu standardowej dyszy, ponieważ odległość pomiędzy sąsiednimi liniami druku można odpowiednio zagęścić.

\subsection{Inspekcja próbki nr 2}

Do wykonania próbki numer 2 zastosowano dyszę o średnicy 0,25 mm. Umożliwiło to wykonanie elementu o mniejszych wymiarach. Ponieważ były to pierwsze realizacje z wykorzystaniem dyszy o mniejszej średnicy, zdecydowano się na wydruk próbki o mniejszych wymiarach gabarytowych. W celu zweryfikowania poprawności nakładania kolejnych warstw, próbka nr 2 została wykonana jako 3-warstwowa. Jej wymiary całkowite wynosiły 11,60 x 11,50 x 2,10 mm. Model rusztowania oraz zdjęcie wykonane za pomocą mikrotomografu przedstawiono na rysunku 2. 


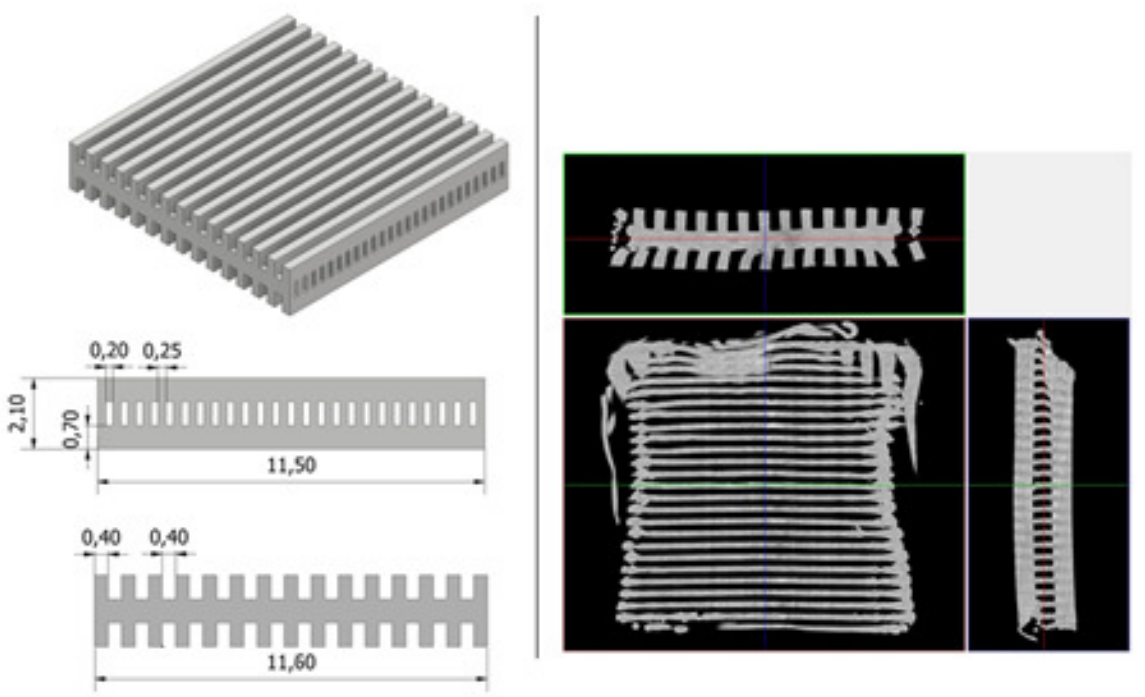

Rysunek 2. Model próbki nr 2 wraz z wymiarami (po lewej stronie) oraz fotografia $\mu C T$ środkowej warstwy rusztowania (po prawej stronie)

\subsection{Inspekcja próbki nr 3}

Do wykonania próbki nr 3 również wykorzystano dyszę o średnicy 0,25 mm. Zdecydowano się na wykonanie 5 warstw, ale o mniejszej wysokości. Całkowite wymiary rusztowania wyniosły $11,60 \times 11,50 \times 2,50 \mathrm{~mm}$. Model rusztowania oraz zdjęcie wykonane za pomocą mikrotomografu przedstawiono na rysunku 3.

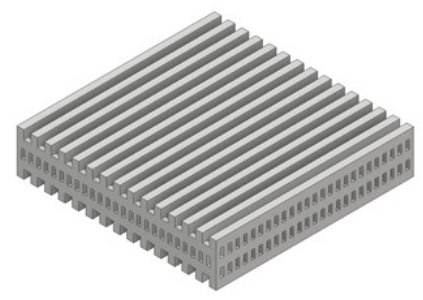

$\stackrel{0,40}{\longrightarrow} \stackrel{0,40}{\longrightarrow} \stackrel{0,25}{\longrightarrow} \stackrel{0,20}{-}$

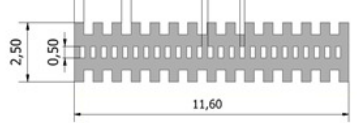

$\underline{0,25} \stackrel{0,20}{-}$

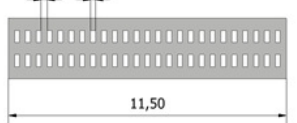

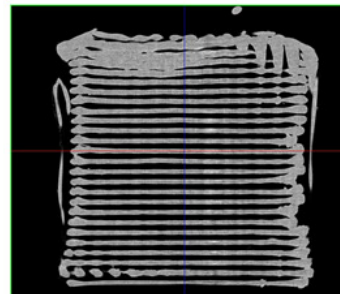

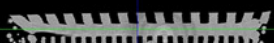

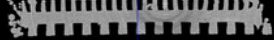

Commuthumere: fiiminumin,

Rysunek 3. Model próbki nr 3 wraz z wymiarami (po lewej stronie) oraz fotografia $\mu C T$ środkowej warstwy rusztowania (po prawej stronie) 


\section{Podsumowanie}

Wszystkie zaprojektowane próbki zostały wydrukowane i przetestowane. Wykorzystanie techniki mikrotomografii komputerowej potwierdziło poprawność wydruku oraz obecność porów o różnej geometrii.

Wszystkie rusztowania zostały zdeformowane w pobliżu jednej ze ścianek. Były to miejsca, w których rozgrzana dysza w trakcie drukowania przebywała najdłużej i prawdopodobnie spowodowała nadtopienie ułożonych już wcześniej warstw modelu. W trakcie kolejnych prób zostaną podjęte działania, mające na celu wyeliminowania tego zjawiska.

Próbki nr 2 i 3 wykonano jako mniejsze od próbki nr 1 ze względu na zastosowaną po raz pierwszy dyszy o mniejszej średnicy. Zostaną podjęte próby wytworzenia większych próbek oraz o bardziej złożonej geometrii.

Dalsze badania będą skupiały się na wprowadzeniu technologii druku 4D do procesu przygotowywania implantów [9, 10].

\section{LITERATURA}

1. PAMUŁA E., BACAKOVA L., FILOVA E., BUCZYŃSKA J., DOBRZYŃSKI P., NOSKOVA L., GRAUSOVA L.: The influence of pore size on colonization of poly(l-lactide-glycolide) scaffolds with human osteoblast-like MG 63 cells in vitro. Journal of Materials Science: Materials in Medicine 19, 425-435 (2008)

2. SOBRAL J. M., CARIDADE S. G., SOUSA R. A., MANO J. F., REIS R. L.: Three-dimensional plotted scaffolds with controlled pore size gradients: Effect of scaffold geometry on mechanical performance and cell seeding efficiency. Acta Biomaterialia 7 (2011), 1009-1018

3. AN J., TEOH J. E. M., SUNTORNNOND R., CHUA C. K.: Design and 3D Printing of Scaffolds and Tissues. Engineering 1, 261-268 (2015)

4. RAJZER I., KUROWSKA A., JABŁOŃSKI A., KWIATKOWSKI R., PIEKARCZYK W., HAJDUGA M. B., KOPEĆ J., SIDZINA M., MENASZEK E.: Scaffolds modified with graphene as future implants for nasal cartilage. Journal of Materials Science 55 (2020), 4030-4042

5. RAJZER I., STRĘK P., WIATR M., SKŁADZIEŃ J., KUROWSKA A., KOPEĆ J., ŚWIEŻY K., WIATR A.: Biomaterials in the Reconstruction of Nasal Septum Perforation. The Annals of otology, rhinology, and laryngology 130, 731-737

6. RAVI, P.: Understanding the relationship between slicing and measured fill density in material extrusion 3D printing towards precision porosity constructs for biomedical and pharmaceutical applications. 3D Print Med 6, 10 (2020).

7. ZHAO H., LI L., DING S., LIU C., AI J.: Effect of porous structure and pore size on mechanical strength of 3D-printed comby scaffolds. Materials Letters 223 (2018), 21-24

8. ABBASI N., HAMLET S., LOVE R. M., NGUYEN N. T.: Porous scaffolds for bone regeneration. Journal of Science: Advanced Materials and Devices 5 (2020), $1-9$

9. DING H., ZHANG X., LIU Y., RAMAKRISHNA S.: Review of mechanisms and deformation behaviors in 4D printing. Int J Adv Manuf Technol 105, 46334649 (2019). 
10. SHIN D. G., KIM T. H., KIM D. E.: Review of 4D printing materials and their properties. Int. J. of Precis. Eng. and Manuf.-Green Tech. 4, 349-357 (2017).

\section{PODZIĘKOWANIA}

Praca finansowana ze środków Narodowego Centrum Nauki w ramach projektu „Warstwowe podłoża wspomagające rekonstrukcję chrząstek nosa wytwarzane metodą druku przestrzennego i elektroprzędzenia" 2015/18/E/ST5/00189 (Sonata Bis 5) oraz ze środków Narodowego Centrum Badań i Rozwoju w ramach projektu: „Warstwowe implanty chrząstek i kości nosa wytwarzane metodą druku 3D" TANGO-IV-A/0002/2019. 